\title{
KAIDAH PENAMAAN LEKSEM BENDA-BENDA KECIL (ISM TAȘGĪR) DALAM KAMUS AL-MUNAWWIR ARAB-INDONESIA (ANALISIS MORFOSEMANTIK)
}

\author{
Muhammad Yunus Anis ${ }^{1,2}$ \\ Arifuddin $^{1}$ \\ ${ }^{1}$ Program Studi Sastra Arab Fakultas Ilmu Budaya \\ Universtias Sebelas Maret Surakarta \\ 2Email: yunus_678@staff.uns.ac.id
}

\begin{abstract}
This article will generally examine the naming convention of small objects lexemes (ism tagir $)$ in the Al-Munawwir Arabic-Indonesian dictionary. The approach used in this study is a linguistic approach, especially closely related to morphosemantics. In this case, the morphosemantic study involves the study of the structure and meaning of the lexeme in relation to small objects or what is commonly referred to in Arabic as ism tașgìr. The research method consists of three important stages, such as: (1) the data collection and analysis using the observation method of linguistic units in the form of "words" in the alMunawwir dictionary, (2) the data analysis used distributional methods in the form of techniques for direct elements and contrasting techniques, and (3) reports on results related to the rules for naming small objects in Arabic. The results of this study are expected to provide new insights on the relationship between morphological word formation in Arabic and naming rules in Semantic studies.
\end{abstract}

Keywords: Lexeme, Morphosemantic, Ism Taṣgìr, Al-Munawwir Indonesian Arabic Dictionary.

$$
\begin{aligned}
& \text { ملخص } \\
& \text { تناقش هذه المقالة ضوابط وضع الكلمات المصغرة الموجودة فن قاموس المنور عربي - إندونيسي. والمنهج المستخدم } \\
& \text { هو منهج لغوي صرفي دلالي، حيث تتركز الدراسة على صيغ الكلمات المصغرة ومعناها في اللغة العربية. وهذه }
\end{aligned}
$$

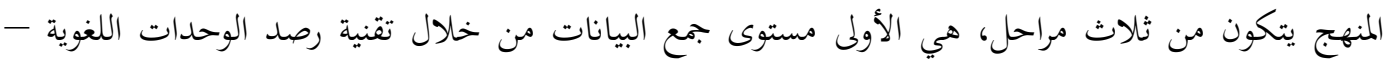

$$
\begin{aligned}
& \text { الكلمات فن قاموس المنور، الثانية تحليل البيانات من خلال تقنية التوزيع المباشر للعناصر اللغوية وتقنية المقابلة، } \\
& \text { الثالثة عرض نتائج التحليل المتعلقة بضوابط وضع الكلمات المصغرة. ويرجى أن تفيد هذه النتائج فن معرفة الآفاق } \\
& \text { الجديدة والعلاقة بين الضوابط الصرفية في تكوين الكلمات والضوابط الدلالية في معنى الألفاظ. } \\
& \text { الكلمات المفتاحية: المفردات، صرف دلالي، اسم التصغير، قاموس المنور عربي- إندونيسي }
\end{aligned}
$$

\section{A. Pendahuluan}

Bahasa bersifat arbiter dan konvensional. Kedua hal tersebut terlihat dalam penamaan benda-benda di alam ini, baik benda dalam ukuran kecil maupun ukuran besar. Apabila kita berbicara tentang "buku", maka pikiran kita akan bergerak kepada sebuah konsep yang sudah tertanam erat sebelumnya tentang apa itu buku, bagaimana bentuknya, ukurannya, fungsinya, warnanya, bahannya, pembuatnya, dll. Konsep tersebut berlandaskan kepada sebuah acuan atau referent yang pernah diketahui sebelumnya. 
$\begin{array}{crr}\text { Untuk } & \text { mempermudah } & \text { dalam } \\ \text { mengungkapkan } & \text { konsep } & \text { yang }\end{array}$ berlandaskan kepada sebuah acuan atau referent dibutuhkan sebuah penamaan atau pemberian nama terhadap sebuah benda yang sudah terkonsep dalam pikiran manusia. Di dalam Kamus Umum Bahasa Indonesia, nama adalah (kata menyatakan) panggilan atau sebutan orang (barang, tempat, dsb) (Poerwadarminta, 1976:670). Proses penamaan tidak terlepas dari beberapa unsur yaitu, lambang, acuan, dan konsep. Ketiganya memiliki hubungan yang erat untuk menentukan nama dari sebuah benda. Seluruh bangsa di dunia ini melakukan proses penamaan untuk mempermudah dalam komunikasi mereka. Penyebutan nama pun berbeda-beda. Kata "buku" dalam bahasa Indonesia berarti "book" dalam bahasa Inggris, dan "kitaabun" dalam bahasa Arab. Proses penamaan ini bersifat arbiter. Artinya, tidak ada hubungan wajib antara lambang/yang menandai (berupa kata atau leksem) dengan referent/yang ditandai (baik benda maupun konsep).

Di satu sisi proses penamaan tersebut, penulis menemukan sebuah keunikan dalam penamaan benda di dalam bahasa Arab. Beberapa penamaan bendabenda kecil di dalam bahasa Arab ternyata mengacu kepada sebuah kaidah atau wazan(pola) khusus. Sebagai contoh, secara arbiter dan konvensional, orang Arab menyebut buku dengan sebutan "kitābun", namun penamaan buku kecil di dalam bahasa Arab dapat dibentuk dari wazan ism taṣgìr, sehingga buku kecil diberi nama "kutaibun" oleh penutur bahasa Arab.

Sejauh pengamatan penulis, penamaan benda-benda kecil sebagai turunan dari kata aslinya ini tidak dimiliki oleh bahasa-bahasa lain. Untuk mengungkapkan konsep ukuran kecil, kebanyakan bahasa mengungkapkannya dengan menambahkan sebuah sifat/adjektiva di samping nama benda yang disifati tersebut, seperti di dalam bahasa Indonesia: buku kecil, pena kecil, dan burung kecil. Begitupula di dalam bahasa Inggris, contoh: small book, small pen, dan small bird.
Berlandaskan pada fakta bahasa tersebut, pembahasan tentang kaidah penamaan benda-benda dalam ukuran kecil di dalam bahasa Arab merupakan pembahasan yang unik. Keunikan ini bertolak dari kekhasan bahasa Arab dalam penamaan benda-benda kecil yang tidak dimiliki oleh bahasa-bahasa lain di dunia ini. Selain itu pengungkapan buku kecil كتابٌ صغير kitābun șagìrun di dalam bahasa Arab, ternyata dapat diungkapkan dengan kata كنيَّب kutaibun yang ternyata memiliki sebuah acuan atau referent yang sama dengan kata كتابٌ صغير (buku kecil). Selanjutnya bagaimana kaidah penamaan benda-benda kecil dalam bahasa Arab tersebut akan dicoba untuk dibahas dan diteliti di dalam makalah sederhana ini. Pembahasan tema ini sangat dekat sekali dengan konsep ism taṣgir di dalam kajian morfologi bahasa Arab. Hal ini dikarenakan penamaan benda-benda kecil dibentuk dari sebuah wazan atau pola khusus di dalam pembentukan sebuah kata. Data utama di dalam penelitian ini diambil dari kamus Al Munawwir Arab Indonesia buah karya Achmad Warson Munawwir. Sejauh pengamatan penulis, penelitian mengenai penamaan bendabenda kecil di dalam bahasa Arab belum pernah diteliti oleh siapa pun

Berdasarkan latar belakang masalah yang dikemukakan di atas, maka pokok masalah dalam penelitian ini adalah bagaimana kaidah penamaan benda-benda kecil di dalam bahasa Arab dan apakah fungsi dari ism tașgīr hanya dikhususkan kepada penamaan benda-benda kecil saja. Masalah pertama erat kaitannya dengan morfologi kata dan masalah kedua melibatkan pembahasan makna, sehingga berhubungan erat dengan kajian semantik.

Tașgì adalah pemberian harakat dammah pada awal kata nomina (isim), pemberian harakat fathah pada huruf yang kedua, dan penambahan $y a^{\prime}$ bersukun setelah huruf kedua tersebut. Ism tașgìr dapat dibentuk dari beberapa kata benda. Apabila kata tersebut tersusun dari tiga huruf konsonan, maka wazan ism taşgir berupa فُ فَعَئ fu'ailun. Apabila kata tersebut tersusun dari empat huruf konsonan, maka

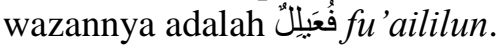


Penelitian ini bersifat sinkronis, artinya hanya melakukan pendekatan terhadap bahasa pada satu waktu tertentu saja. Dalam hal ini peneliti tidak melakukan kajian historis sama sekali dalam pembahasan dan analisis masalah. Data penelitian (bahan penelitian, bahan jadi penelitian) yang digunakan dalam penelitian ini adalah kata-kata yang mengandung morfem-morfem pembentuk ism taşgìr di dalam kamus Al Munawwir Arab Indonesia yang diterbitkan pada tahun 2002. Sedangkan objek penelitian (sasaran penelitian, gegenstand) yang dibahas dalam penelitian ini adalah morfem-morfem pembentuk ism taṣgīr dan kaidah pembentukannya sebagai proses penamaan benda-benda kecil di dalam bahasa Arab.

Pertama kali data yang berupa kata-kata yang mengandung morfemmorfem pembentuk ism taşgì diinventariskan ke dalam kartu data. Kemudian dipilah berdasarkan polapola(wazan)nya. Metode pembahasan yang digunakan adalah metode agih dengan menggunakan teknik dasar berupa teknik bagi unsur langsung dan teknik pengontrasan.

\section{B. Kerangka Teoritis}

Studi bahasa pada dasarnya merupakan peristiwa budaya, melalui bahasa manusia menunjuk dunianya. Dunia ini penuh dengan nama-nama yang diberikan oleh manusia. Manusia tidak hanya memberi nama, tetapi memberi makna pula. Bahkan, dirinya pun diberi nama dan bermakna pula.

Nama merupakan kata-kata yang menjadi label setiap makhluk, benda, aktivitas, dan peristiwa di dunia ini. Anakanak mendapat kata-kata dengan cara belajar, dan bunyi-bunyi yang mereka dengar untuk pertama kalinya. Namanama ini muncul akibat dari kehidupan manusia yang komplek dan beragam, alam sekitar manusia berjenis-jenis. Kadangkadang manusia sulit memberikan label satu per satu, oleh karena itu, muncul nama-nama kelompok, misalnya, binatang, burung, ikan, dan tumbuhtumbuhan (tak terhitung jumlah jenis binatang, jenis burung, jenis tumbuhan yang ada di dunia ini).

Di dalam kehidupan sehari-hari ada kata yang mudah dihubungkan dengan bendanya, ada pula yang sulit dan tidak mengacu kepada benda nyata (konkret), lebih mengacu kepada pengertian. Katakata yang tidak mengacu kepada benda: demokrasi, korupsi, partisipasi, deskripsi, dan argumentasi.

Kata-kata yang tidak dapat dihayati wujudnya tersebut, berbeda dengan kata-kata yang dapat dihayati wujudnya (konkret), misalnya: kursi, meja, dan gunung.

Penamaan di tiap daerah atau lingkungan kebudayaan tertentu bagi benda yang sama tentunya berbeda, misalnya, padi (bahasa Indonesia), pare (bahasa Sunda), ada pula yang menyebut pale (Gorontalo). Masalah yang muncul sehubungan dengan perbedaan nama tersebut ialah apakah hubungan nama dengan benda. Beberapa orang ahli berpendapat:

1. Plato (429-348 SM)

Ada hubungan hayati antara nama dan benda (kata-kata merupakan nama-nama, sebagai label dari benda-benda, atau peristiwa). Pertanyaan yang muncul dari Plato sendiri; apakah pemberian nama kepada benda secara sewenang-wenang atau dengan perjanjian; apakah penamaan berdasarkan faktor sukarela atau dengan perjanjian dari semua pihak Jawabannya dapat dibaca di dalam Cratylous.

2. Aristoteles (384-322 SM) (Murid Plato)

Mengatakan bahwa pemberian nama adalah soal perjanjian (bukan berarti dahulu ada sidang nama untuk sesuatu yang diberi nama). Nama biasanya dari seseorang (ahli, penulis, pengarang, pemimpin negara atau masyarakat baik melalui media masa elektronika, atau majalah dan koran). Misalnya, di dalam fisika kita kenal hokum Boyle, dan Archimedes. Dalam 
permainan kita kenal sepak bola, tenis meja, tenis, dsb. Nama sesuatu kadang-kadang dapat diusut asal-usulnya. Misalnya, nama tempat di Indonesia: Banyuwangi, Sunda Kelapa, Pandeglang.

Setiap cabang ilmu memberikan nama tertentu untuk benda, fakta, kejadian, atau proses, misalnya, garam, = NaCI, di dalam ilmu bahasa (linguistik) dikenal istilah: fonem, morfem, taksem, semem, dsb.

3. Socrates (469-399 SM), guru Plato, yang mengemukakan bahwa nama harus sesuai dengan sifat acuan yang diberi nama. Pendapatnya merupakan kebalikan dari yang dikemukakan Aristotles.

Nama tertentu yang bersifat khusus untuk setiap bidang ilmu, disebut istilah. Setiap bangsa memiliki nama sendiri untuk setiap benda. Tiap negara berbeda dengan negara lain. Tiap daerah memiliki nama-nama yang berbeda dengan negara lain. Tiap daerah memiliki nama-nama yang berbeda untuk benda yang sama, atau kadang-kadang nama dan benda yang ada di suatu daerah tidak ditemukan di daerah lain. Sebagai contoh dapat dikemukakan, di Bandung lauk, Jakarta ikan, di Jawa iwak. Ekspresi tertentu dapat ditemukan di dalam bahasa tertentu, tetapi tidak didapati di dalam bahasa Indonesia, misalnya, bila seseorang bersin, orang yang mendengarnya selalu mengatakan: hurip waras! (bahasa Sunda), God bless you! (bahasa Inggris), Gezondheid! (bahasa Belanda), Gesundheit! (bahasa Jerman).

Masalah yang muncul sehubungan dengan nama, apakah nama ada hubungannya dengan istilah dan definisi? Nama berupa kata atau kata-kata yang merupakan label dari makhluk, benda, aktivitas, dan peristiwa. Istilah adalah nama tertentu yang bersifat khusus atau suatu nama yang berisi kata atau gabungan kata yang cermat, mengungkapkan makna, konsep, proses, keadaan, atau sifat yang khas di bidang tertentu. Definisi adalah nama yang diberi keterangan singkat dan jelas di bidang tertentu.

Suatu nama dapat berfungsi sebagai istilah; istilah-istilah akan menjadi jelas bila diberi definisi, demikian pula nama. Istilah sama halnya dengan definisi, keduanya berisi pembatasan tentang suatu fakta, peristiwa atau kejadian, dan proses.

Sebagai gejala budaya, bahasa bersifat dinamis, bahasa tumbuh dan berkembang sejalan dengan meningkatnya kemajemukan persepsi manusia terhadap makrokosmos (dunia sekitarnya) dan mikrokosmos (dunia pribadinya). Gejala ini tidak didapati pada makhluk lain. Nama-nama bila diperhatikan tidak hanya nama benda atau peristiwa yang disekitarnya ada yang berubah, nama baru (kosa kata baru) pun muncul dari zaman ke zaman. Unsur nama-nama (kosa kata) adalah unsur bahasa yang paling labil, perhatikanlah kata-kata berikut dengan pergeseran, pertahanan, dan perkembangan maknanya:

1. Akibat peristiwa dunia: negosiasi, malvinas, dan perang bintang

2. Akibat kemajuan teknologi: televisi, computer, dan satelit.

Telah dikatakan bahwa bahasa adalah sistem tanda yang digunakan untuk berkomunikasi. Tanda yang dimaksud disini berupa lambang. Lambang dalam bahasa berisi dua, yakni bentuk (expression, signifier), dan makna (contents, signified). Salah satu pendapat tertua yang dikemukakan oleh Plato di dalam suatu percakapan yang berjudul Cratylus atau Cratylos, lambang adalah kata di dalam suatu bahasa, sedangkan makna adalah objek yang kita hayati di dunia nyata berupa acuan yang ditunjukkan oleh lambang tersebut. Karena itu, kata-kata dapat kita katakan sebagai nama label setiap benda, aktivitas, atau peristiwa.

Pemberian nama benda-benda kecil sangat erat hubungannya dengan konsep ism taşgīr di dalam bahasa Arab. Kata asli menderivasikan dirinya sendiri dengan wazan ism tasgīr menjadi kata jadian yang memiliki makna benda berukuran kecil. Contoh: secara arbitrer 
dan konvensional orang Arab menyebut bolpen dengan قلم qalamun. Kata tersebut berubah menjadi قليم qulaimun yang berarti bolpen kecil. Hal senada sebenarnya juga قلم dapat diungkapkan dengan menyebut qalamun shagìrun, tapi pemanfaatan wazan ism taṣgìr di dalam komunikasi bahasa Arab dianggap lebih memiliki kekayaan kosakata di dalam proses komunikasi.

Al-Ghulayaini mendefinisikan tașgìr sebagai pemberian harakat dhamah pada awal kata nomina (ism), pemberian harakat fathah pada huruf yang kedua, dan penambahan ya' sakinah (mati) setelah huruf kedua tersebut. Selanjutnya huruf ya' tersebut disebut dengan $y a^{\prime}$ tassgìr. Contoh: قلم (qalamun) menjadi bentuk ism taşgir قليم (qulaimun), درهم (dirhamun) menjadi عصـفور (duraihimun), عريهـ ("usur) ('uṣfürun) menjadi عصيف ('uṣaifirun), حسين (hasanun) menjadi حسين (husainun), dan زهر زهير (zahrun) menjadirun).

Kata benda nomina yang dikenai ya' tașgìr disebut dengan musaggar atau ism musoggar (diminutive noun). Syaratsyarat tasgi $\bar{r}$ menurut Al-Ghulayaini adalah:

1. Ism yang berterima dengan bentuk tașgīr adalah ism mu'rab (declined noun) sedangkan ism mabni seperti kata ganti tidak berterima dengan bentuk taşgir .

2. Kata tersebut dapat menerima pengertian tasgì $r$. Bentuk tasgì $r$ tidak berasal dari kata yang tidak berterima dengan bentuk taşgir .

3. Kata tersebut terlepas dari bentuk taşgir dan yang menyerupainya. Bentuk taşgìr tidak berasal dari kata yang berasal dari kata yang sama dengan bentuk tașgìr.

4. Bentuk tașgìr tidak berasal dari kata kerja dan partikel.

5. Bentuk tașgīr tidak berasal dari isim mabni (structured noun). Pengecualian yang kedua berasal dari ism maușūl dan ism isyārah. Contoh:

$$
\text { ذيا - تأي =تيا للذيا - التي = اللتيـا - ذا= }
$$

Di dalam analisis masalah akan dibahas dua hal penting, yaitu (1) proses penamaan benda-benda kecil di dalam bahasa Arab dan (2) wazan, kaidah, dan fungsi dari ism tasgìr. Proses penamaan di dalam bahasa Arab dimulai dari:

1. Pengertian Makna

2. Pengertian Simbol

3. Pengertian Acuan

Sedangkan di dalam pembahasan ism tașgìr sebagai salah satu cara penamaan benda-benda dalam ukuran kecil di dalam bahasa Arab akan dimulai dengan pembahasan:

1. Wazan ism tașgìr untuk fi'l tsulāsī, dan rubā' $i$.

2. Kaidah pembentukan ism tașgīr secara morfologis.

3. Fungsi ism tașgìr secara semantik. Data utama dalam penelitian ini adalah kata-kata benda yang terdapat di dalam kamus Al Munawwir. Pengambilan data dikelompokkan menjadi dua kelompok. Kelompok satu berupa kata benda yang tersusun dari tiga huruf, seperti: كتاب (buku), بحر (laut), كلب (anjing), باب (bintu), ظكّل (pemuda laki-laki).

Kelompok dua merupakan katakata yang tersusun dari empat huruf, seperti: عقرب (laba-laba), مسلم (muslim), مسلمة (muslimah).

\section{Pengertian Makna}

Kata ma'na, dalam ilmu semantik, sering disebut "tanda" (dalālah). Al Khuli mendefinisikan, makna/tanda (meaning) adalah:

$$
\text { الكلمة أو العبارة أو الجملة. المعلة : ما يفهمه الثخص من }
$$

Makna/Tanda adalah sesuatu yang dipahami seseorang, baik berasal dari kata, ungkapan, maupun kalimat (Al Khuli, 1982:166).

Secara etimologi, kata ma'na berasal dari yang salah satu maknanya ialah melahirkan. Karena itu, makna diartikan sebagai perkara yang dilahirkan dari tuturan. Perkara tersebut ada di dalam benak manusia sebelum diungkapkan dalam sarana bahasa. Sarana ini berubahubah sesuai dengan perubahan makna tersebut di dalam benak. Perkara yang 
terdapat di dalam benak disimpulkan sebagai hasil pengalaman yang diolah akal secara tepat.

Hubungan antara lafal/bahasa (intra lingual) dengan sesuatu yang ada di luar bahasa (ekstra lingual) dikenal dengan teori "semantic triangle" (mutsallats al-ma'nā), yaitu segitiga bermakna yang menghubungkan antara 3 aspek dasar, yakni:

1. Simbol/kata/signifiant/penanda (dalālāh) yang terdiri dari bunyi bahasa, tulisan, isyarat dan sebagainya, seperti: kata kitab (buku).
2. Konsep/benak/pikiran/mind (syu'ür/fikrah) yang ada di dalam diri manusia ketika memahami kata.

3. Acuan/benda/sesuatu/referen/signi fy/petanda (madlül/musyār ilaih) yang ditunjuk dari kata.

Dalam bahasa semiotika, tanda (sign) terdiri dari dua unsur yang tidak bisa dipisahkan, yaitu penanda (signifiant) dan petanda (signify). Penanda adalah aspek material dari bahasa, sedangkan petanda adalah makna (konsep) yang ada dalam pikiran (mind). Perhatikan ilustrasi 'segitiga bermakna' pada gambar berikut ini.

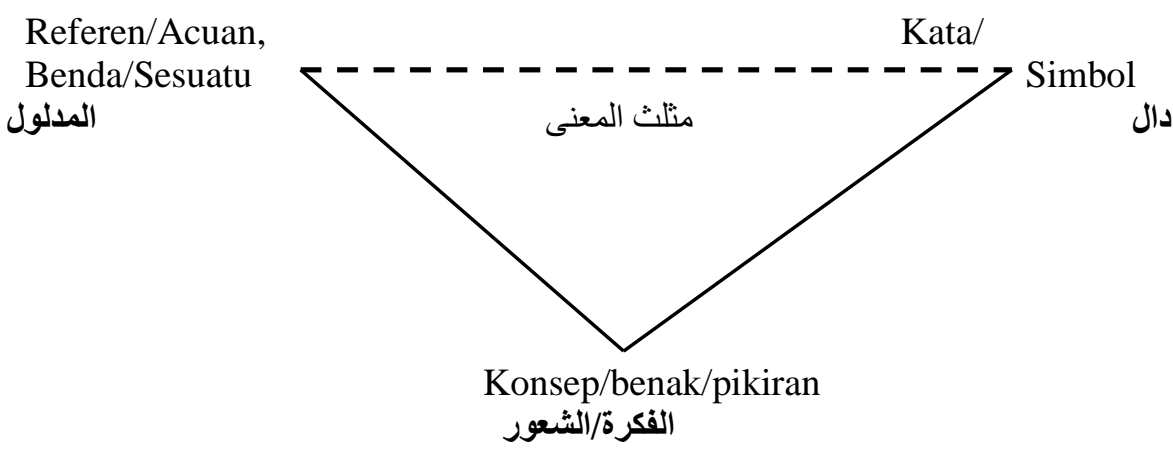

Menurut teori "semantic triangle" di atas, hubungan yang terjalin antara sebuah bentuk "kata/simbol" dengan "acuan/benda/hal/peristiwa" di luar bahasa tidak bersifat langsung (muqattha'ah), tetapi ada media yang terletak di antara keduanya, yaitu benak/ pikiran/konsep. Kata hanya merupakan lambang (simbol) yang berfungsi menghubungkan konsep/pikiran dengan acuan/benda.

Tidak semua kata/simbol memiliki acuan/benda. Misalnya, kata walaupun, aduh, sekalipun bermakna tetapi tidak menunjuk sesuatu, tidak ada referennya. Berbeda dengan kata 'pensil' yang memiliki referen sebab ia menunjuk pada sesuatu (sebuah benda yang terbuat dari kayu dan biasa digunakan untuk menulis). Apabila kata/simbol dalam realita memiliki acuan dan melahirkan makna, maka makna itu disebut dengan makna referensial. Makna referensial (al$m a$ 'nā al-marja'i) adalah makna yang berhubungan langsung dengan kenyataan atau referent (acuan). Makna referensial juga disebut makna kognitif (al-ma'nā alma'rifi), makna afektif (al-ma'nā alwujdānī) dan makna emotif (al-ma'nā al'ạtifí).

\section{Pengertian Simbol}

Pembahasan tentang simbol, dalam linguistik, kini telah dikaji secara khusus di dalam ilmu semiotika ('ilm al'alāmāt). Secara etimologi, semiotik berasal dari bahasa Yunani 'semeion' yang diambil dari kata 'sema' berarti 'tanda'. Semiotika membahas tentang macam-macam tanda/ simbol/ isyarat yang terdapat pada fenomena bahasa.

Pierce membedakan 'tanda' menjadi tiga macam, yaitu:

1. Iconic Sign (al-'alāmah aliqūniyyah)

Yaitu, tanda yang menjelaskan acuan/benda-nya melalui cara imitasi (muhākah), seperti: 
gambar benda, lukisan, peta, patung, dan sebagainya.

2. Indexical Sign (al-'alāmah alisyāriyyah)

Yaitu, tanda yang menjelaskan acuan/benda-nya melalui adanya hubungan yang lazim/biasa, seperti asap adalah tanda adanya api, suara mengeong adalah tanda adanya kucing, jejak atau sidik jari tangan adalah tanda adanya pencuri, dan sebagainya.

3. Symbol (al-ramz)

Yaitu, tanda yang menjelaskan acuan/benda-nya melalui adanya makna istilah yang telah disepakati manusia, seperti: rambu-rambu lalu lintas, simbol 冈 berarti salah dan simbol $\square$ berarti benar, simbol musik, suara bel, dan sebagainya, termasuk juga kosakata bahasa, misalnya: شجرة (pohon), حصان (kuda), dan lain sebagainya.

\section{Pengertian Acuan}

Acuan/sesuatu/benda yang juga disebut "petanda" (madlūl/musyār ilaih) merupakan komponen ketiga yang menjadi bahasan semantik, terutama dalam kaitannya dengan teori 'segitiga makna'. Acuan adalah sesuatu atau benda yang ditunjuk oleh kata/bahasa dan bertempat di luar kata/bahasa, baik sesuatu tersebut bersifat realistis (haqīqah), imajinatif (khayāliyyah), maupun ilusi (wahmiyyah). Acuan dibedakan menjadi dua macam, yaitu: (1) acuan yang berkaitan atau berada di dalam bahasa itu sendiri, dan (2) acuan yang berkaitan atau berada di luar bahasa.

1. Acuan di dalam bahasa Yaitu, beberapa kosakata atau istilah yang ditujukan ke hal-hal yang berada di dalam bahasa. Misalnya, istilah-istilah seperti: fail(subyek), maf'ul(obyek), isim jumlah, kalimah, musnad, musnad ilaih, dan sebagainya. Istilahistilah(simbol) ini mengacu kepada kedudukan atau makna kebahasaan yang berada di dalam bahasa.
2. Acuan ke luar-bahasa

Yaitu, acuan/benda/sesuatu yang berada di luar bahasa, baik bersifat riil di alam semesta maupun tidak. Acuan luar bahasa dapat diklasifikasikan sebagai berikut:
a. Acuan
Inderawi

(sensory/hissiyyah)

Yaitu sesuatu di alam semesta yang bisa ditangkap oleh panca indera manusia, seperti: bendabenda(gunung/جبال,

pohon/شجرة/شatahari, dsb); sifat-sifat(panjang/طويل/شيرة/, merah/كمر, أحبير/ besar, dsb);

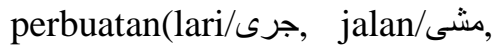
tidur/نام, dsb)

b. Acuan

Metafisik/Transendental

(Gaibiyyah)

Yaitu sesuatu yang bisa dikenal melalui pengetahuan yang berasal dari kitab-kitab agama, seperti: jin, malaikat, iblis, sorga, dan sebagainya.

c. Acuan Ilusi (Wahmiyyah)

Yaitu sesuatu yang tidak ada wujudnya dalam kenyataan,

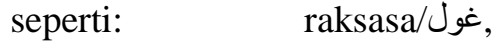
kuntilanak/سعلاء, binatang khayalan; badan singa, kepala dan sayap seperti elang/عنقاء

d. Acuan Imajinatif (Khayāliyyah)

Yaitu sesuatu yang tidak ada wujudnya, akan tetapi ia tergambar melalui hal-hal yang ada/wujud dalam realita, seperti: pribadi tokoh yang ada di dalam cerita atau novel, deskripsi tentang perempuan yang tertuang dalam bait-bait syair, pribadi aktor film, drama, dan sebagainya.

e. Acuan Abstrak (Ma'nawiyyah) Yaitu sesuatu yang secara fisik tidak ada wujudnya, akan tetapi ia dipahami secara logis, misalnya: sifat jujur/الصدق/, keadilan/العدل,

kedermawanan/الكرم/العر, dan sebagainya. 
f. Acuan Mutlak (Absolut/Mujarradah)

Yaitu sesuatu yang mutlak berada di luar, tetapi ia tidak terfokus/tertentu pada sesuatu. Dalam ilmu nahwu acuan mutlak isim jenis. Misalnya, hewan/حيوان, manusia/انسان, orang laki-laki/رجل, dan sebagainya.

\section{Pembahasan}

Tașgì adalah pemberian harakat dhamah pada awal kata nomina (ism), pemberian harakat fathah pada huruf yang kedua, dan penambahan $y a^{\prime}$ sakinah (mati) setelah huruf kedua tersebut. Ism taşir dapat dibentuk dari beberapa kata benda. Apabila kata tersebut tersusun dari tiga huruf konsonan, maka wazan ism taṣgìr berupa فُعَئ Apabila kata tersebut tersusun dari empat huruf konsonan, maka wazannya adalah فُعَيَّ.

Contoh kata-kata yang tersusun dari tiga konsonan beserta bentuk tașīrnya yang diambil dari kamus $\mathrm{Al}$ Munawwir Arab Indonesia adalah sebagai berikut:

\begin{tabular}{|c|c|c|c|}
\hline كتاب & Buku (Hal.1275) & كتيب & Buklet \\
\hline بحر & Laut (Hal.64) & بحيرة & Laut kecil \\
\hline كلب & Anjing (Hal.1312) & كليب & Anjing kecil \\
\hline باب & Pintu (Hal.126) & بويب & Pintu kecil \\
\hline ظلّ & Bayangan (Hal.945) & ظليل & Bayangan kecil \\
\hline شابّ & Pemuda (Hal.736) & شبيب & Pemuda kecil \\
\hline
\end{tabular}

\section{1. كتيب > (Buku Kecil)}

Kata كitābun mengandung bentuk taṣgīr yaitu kata كنَب kutaibun yang dimaksudkan untuk mengecilkan ukuran benda. Kata tersebut menggunakan

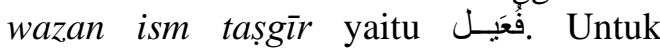
menentukan bagian-bagian fungsional, penulis memanfaatkan teknik bagi unsur langsung. Kata "كتَب adalah bentuk kata "polimorfemis" yang berasal dari bentuk dasar berupa kata benda (ism) yaitu كتاب. Selanjutnya kata tersebut mendapatkan tambahan morfem yang berupa harakat dhammah di awal kata dan harakat fathah pada huruf kedua. Selanjutnya penambahan morfem ya' mati sebelum akhir sehingga terbentuklah kata "كُّ تَّي ب' yang digunakan untuk penamaan bendabenda kecil di dalam bahasa Arab.

Kata كتَب menggunakan wazan " فُعَيل yang berfungsi untuk menunjukkan bentuk tasgīr dalam bahasa Arab. Upaya pengontrasan antara kata asli dengan ism taṣgì (diminutive) membuktikan bahwa kata كتيب merupakan salah satu bentuk ism tasgìr.

(1) (Kata yang secara arbiter dan konvensional dalam penamaan benda) berarti "buku".
(2) كنَبـ (sentuk diminutive dari kata كتاب) berarti:"buku kecil"

Penambahan morfem harakat dhammah di awal kata dan morfem harakat fatkhah pada huruf kedua dan ya' mati sebelum akhir pada kata كتاب dengan فُعَيـل menyamakan pada pola/wazan mengakibatkan perbedaan makna pada contoh (1) dan (2). Akhirnya dapat disimpulkan bahwa kata كنَب merupakan bentuk diminutive pada sebuah kata benda. Proses pembentukannya diperoleh dengan cara menambahkan morfem harakat dhammah, fatkhah, dan ya' sakinah.

\section{2. بحيرة > (Laut) بحر (Laut Kecil)}

Kata بحر bahrun mengandung bentuk tașīr yaitu kata بحيرة buhairatun yang dimaksudkan untuk mengecilkan ukuran benda. Kata tersebut menggunakan wazan ism tașgìr yaitu فُ فُعَّ.

Untuk menentukan bagian-bagian fungsional pada kata tersebut, penulis memanfaatkan teknik bagi unsur langsung. Kata "بحيرة adalah bentuk kata "polimorfemis". Kata tersebut berasal dari bentuk dasar yang berupa kata benda(ism) yaitu بحـر. Selanjutnya kata tersebut mendapatkan tambahan morfem yang 
berupa harakat dhammah di awal kata dan harakat fathah pada huruf kedua. Selanjutnya penambahan morfem ya' sakinah sebelum akhir sehingga terbentuklah kata بُ حَ ب yang digunakan untuk penamaan benda-benda kecil di dalam bahasa Arab.

Kata بحيرة menggunakan wazan . فُعَيـل" Wazan tersebut berfungsi untuk menunjukkan bentuk taṣgīr dalam bahasa Arab. Upaya pengontrasan antara kata asli dengan ism tașgīr(diminutive) akan membuktikan bahwa kata بحيرة merupakan salah satu bentuk ism taşgir.

(1) بحر (Kata yang secara arbiter dan konvensional dalam penamaan benda) berarti "laut".

(2) بحيرة (bentuk diminutive dari kata بحر) berarti:"laut kecil"

Penambahan morfem harakat dhammah di awal kata dan morfem harakat fatkhah pada huruf kedua dan ya' sakinah sebelum akhir pada kata بحر dengan menyamakan pada pola/wazan فُعَيل mengakibatkan perbedaan makna pada contoh (3) dan (4). Akhirnya dapat disimpulkan bahwa kata بحيرة merupakan bentuk diminutive pada sebuah kata benda. Proses pembentukannya diperoleh dengan cara menambahkan morfem harakat dhammah, fatkhah, dan ya' sakinah.

\section{كليـب >- Anjing) hal.1312 كلب (Anjing Kecil)}

Kata tersebut mengandung bentuk taṣgīr yaitu kata كليب yang dimaksudkan untuk mengecilkan ukuran benda. Kata tersebut menggunakan wazan ism taşgīr yaitu فُعَّيـ. Untuk menentukan bagianbagian fungsional pada kata tersebut, penulis memanfaatkan teknik bagi unsur langsung. Kata "كليب adalah bentuk kata "polimorfemis". Kata tersebut berasal dari bentuk dasar yang berupa kata benda(ism) yaitu كنب. Selanjutnya kata tersebut mendapatkan tambahan morfem yang berupa harakat dhammah di awal kata dan harakat fathah pada huruf kedua. Selanjutnya penambahan morfem ya' sakinah sebelum akhir sehingga terbentuklah kata كُ لَّ ب بُ yang digunakan untuk penamaan benda-benda kecil di dalam bahasa Arab.

Kata كليب menggunakan wazan . فُعَيـل Wazan tersebut berfungsi untuk menunjukkan bentuk taşgìr dalam bahasa Arab. Upaya pengontrasan antara kata asli dengan ism tașirr(diminutive) akan membuktikan bahwa kata كليب merupakan salah satu bentuk ism tașgìr.

(1) كلب (Kata yang secara arbiter dan konvensional dalam penamaan benda) berarti "anjing".

(2) كليب (bentuk diminutive dari kata كلب) berarti:"anjing kecil"

Penambahan morfem harakat dhammah di awal kata dan morfem harakat fatkhah pada huruf kedua dan ya' sakinah sebelum akhir pada kata كلب dengan menyamakan pada pola/wazan فُعَيلب mengakibatkan perbedaan makna pada contoh (5) dan (6). Akhirnya dapat disimpulkan bahwa kata كليب merupakan bentuk diminutive pada sebuah kata benda. Proses pembentukannya diperoleh dengan cara menambahkan morfem harakat dhammah, fatkhah, dan ya' sakinah.

\section{4. بويب - (Pintu) hal 126 (Pintu Kecil)}

Kata tersebut mengandung bentuk taṣgīr yaitu kata بويب yang dimaksudkan untuk mengecilkan ukuran benda. Kata tersebut menggunakan wazan ism taṣgìr yaitu فُعَـــ Untuk menentukan bagianbagian fungsional pada kata tersebut, penulis memanfaatkan teknik bagi unsur langsung. Kata "بويب adalah bentuk kata "polimorfemis". Kata tersebut berasal dari bentuk dasar yang berupa kata benda $(i s m)$ yaitu بـاب. Selanjutnya kata tersebut mendapatkan tambahan morfem yang berupa harakat dhammah di awal kata dan harakat fathah pada huruf kedua. Selanjutnya penambahan morfem ya' sakinah sebelum akhir sehingga terbentuklah kata بُ وَ ي بُ yang digunakan untuk penamaan benda-benda kecil di dalam bahasa Arab.

Kata بويب menggunakan wazan "فُعَيـل Wazan tersebut berfungsi untuk menunjukkan bentuk tașgìr dalam bahasa 
Arab. Upaya pengontrasan antara kata asli dengan ism tașgīr (diminutive) akan membuktikan bahwa kata بويب merupakan salah satu bentuk ism taṣgìr.

(1) بـاب (Kata yang secara arbiter dan konvensional dalam penamaan benda) berarti "pintu".

(2) بويـب (ب) dentuk diminutive dari kata باب) berarti:"pintu kecil"

Penambahan morfem harakat dhammah di awal kata dan morfem harakat fatkhah pada huruf kedua dan ya' sakinah sebelum akhir pada kata بـاب dengan menyamakan pada pola/wazan فُعَيل mengakibatkan perbedaan makna pada contoh (7) dan (8). Akhirnya dapat disimpulkan bahwa kata بويب merupakan bentuk diminutive pada sebuah kata benda. Proses pembentukannya diperoleh dengan cara menambahkan morfem harakat dhammah, fatkhah, dan ya' sakinah.Dalam proses penamaan bendabenda kecil huruf alif pada kata بـاب dikembalikan ke bentuk asalnya yaitu huruf waw.

\section{5ليـ > - Bayangan) hal.945 ظلّ (Bayangan Kecil)}

Kata tersebut mengandung bentuk taṣgir yaitu kata ظليل yang dimaksudkan untuk mengecilkan ukuran benda. Kata tersebut menggunakan wazan ism tașgīr yaitu فُعَئ Untuk menentukan bagianbagian fungsional pada kata tersebut, penulis memanfaatkan teknik bagi unsur langsung. Kata "ظليل adalah bentuk kata "polimorfemis". Kata tersebut berasal dari bentuk dasar yang berupa kata benda(ism) yaitu ظـــ Selanjutnya kata tersebut mendapatkan tambahan morfem yang berupa harakat dhammah di awal kata dan harakat fathah pada huruf kedua. Selanjutnya penambahan morfem ya' sakinah sebelum akhir sehingga terbentuklah kata ظُّنَ ئل yang digunakan untuk penamaan benda-benda kecil di dalam bahasa Arab.

Kata ظenggunakan wazan . فُعَيَل Wazan tersebut berfungsi untuk menunjukkan bentuk taṣgīr dalam bahasa Arab. Upaya pengontrasan antara kata asli dengan ism tașgīr (diminutive) akan membuktikan bahwa kata ظليـ merupakan salah satu bentuk ism taṣgir .

(1) ظلّ dan konvensional dalam penamaan benda) berarti "bayangan".

(2) ظليـل (bentuk diminutive dari kata ظـ berarti:"bayangan kecil"

Penambahan morfem harakat dhammah di awal kata dan morfem harakat fatkhah pada huruf kedua dan ya'

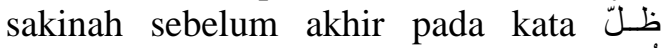
dengan menyamakan pada pola/wazan فُعَيل mengakibatkan perbedaan makna pada contoh (9) dan (10). Akhirnya dapat disimpulkan bahwa kata ظليل merupakan bentuk diminutive pada sebuah kata benda. Proses pembentukannya diperoleh dengan cara menambahkan morfem harakat dhammah, fatkhah, dan ya' sakinah.Dalam proses penamaan bendabenda kecil di dalam bahasa Arab huruf bertasydid harus diurai.

\section{6. شسبي > - (Pemuda Kecil)}

Kata tersebut mengandung bentuk taṣgīr yaitu kata شبيب yang dimaksudkan untuk mengecilkan ukuran benda. Kata tersebut menggunakan wazan ism tașgir yaitu فُعَيـل Untuk menentukan bagianbagian fungsional pada kata tersebut, penulis memanfaatkan teknik bagi unsur langsung. Kata "شبيب" adalah bentuk kata "polimorfemis". Kata tersebut berasal dari bentuk dasar yang berupa kata benda(ism) yaitu شــابّ. Selanjutnya kata tersebut mendapatkan tambahan morfem yang berupa harakat dhammah di awal kata dan harakat fathah pada huruf kedua. Selanjutnya penambahan morfem ya' sakinah sebelum akhir sehingga terbentuklah kata شُ بُ بي بُ yang digunakan untuk penamaan benda-benda kecil di dalam bahasa Arab.

Kata شـبيب menggunakan wazan "فُعَســ Wazan tersebut berfungsi untuk menunjukkan bentuk taṣgī dalam bahasa Arab. Upaya pengontrasan antara kata asli dengan ism tașgir(diminutive) akan membuktikan bahwa kata شبيب merupakan salah satu bentuk ism tașgìr. 
(1)

شـابّ (Kata yang secara arbiter dan konvensional dalam penamaan benda) berarti "pemuda".

(2) شـentuk diminutive dari kata ثــابّ) berarti "pemuda kecil"

Penambahan morfem harakat dhammah di awal kata dan morfem harakat fatkhah pada huruf kedua dan ya' sakinah sebelum akhir pada kata شَّبّ dengan menyamakan pada pola/wazan فُعَيل mengakibatkan perbedaan makna pada contoh (11) dan (12). Akhirnya dapat disimpulkan bahwa kata شبيب merupakan bentuk diminutive pada sebuah kata benda. Proses pembentukannya diperoleh dengan cara menambahkan morfem harakat dhammah, fatkhah, dan ya' sakinah. Dalam proses penamaan bendabenda kecil di dalam bahasa Arab huruf bertasydid harus diurai.

Kata-kata yang tersusun dari empat huruf konsonan memiliki wazan bentuk taṣgìr = فُعَيل Contoh:

\begin{tabular}{|c|c|c|c|}
\hline عقرب & Laba-laba (Hal.1025) & عُقَيَرِبُ & Laba-laba kecil \\
\hline مسلم & Muslim (Hal.701) & مُسَبَلٌِْ & kecil \\
\hline مسلمة & Muslimah (Hal.701) & 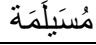 & Muslimah kecil \\
\hline
\end{tabular}

Dalam proses pembentukan ism tasgìr sejumlah kaidah morfologi yang berlaku adalah sebagai berikut:

Apabila kata-kata tersebut berasal dari double verb (fi'l mudha'af) maka bentuk taṣgīrnya dikembalikan kepada bentuk asli yang lengkap seperti pada طلّ , شابّ : contoh

Apabila kata-kata tersebut mengandung huruf 'illah (weak radicals), maka huruf 'illah yang telah diganti tersebut harus dikembalikan kepada bentuk asalnya. Seperti dalam kata بويب, huruf waw diganti menjadi huruf alif, sehingga menjadi kata باب

Huruf akhir penanda femina tetap dipakai di dalam kata pengecil (ism tașgìr). Contoh:

\begin{tabular}{|c|c|c|c|}
\hline قلعة & Benteng (Hal.1237) & قُلْيعة & Benteng Kecil \\
\hline شجرة & Pohon (Hal.743) & شُشجَيرة & Pohon Kecil \\
\hline مدّة & Periode (Hal.1413) & مُدَيَدَة & Sebentar \\
\hline
\end{tabular}

Bentuk tașgìr juga berterima memiliki huruf akhir penanda dengan kata benda feminin yang tidak ta'nist(femina). Contoh:

\begin{tabular}{|c|c|c|c|}
\hline شمس & Matahari (Hal.792) & شُشَمَيسَة & Matahari Kecil \\
\hline دار & Rumah (Hal.465) & دُوَيرَةُ & Rumah Kecil \\
\hline 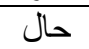 & Keadaan (Hal.336) & حُوَيلَّة & Keadaan kecil \\
\hline
\end{tabular}

Apabila kata-kata tersebut dalam pembentukan bentuk taṣgīr. tersusun dari lima konsonan, maka satu huruf konsonan terakhir harus dihapus

\begin{tabular}{|c|c|c|c|}
\hline عنديدل & Burung Malam (Hal.1049) & Burung Malam Kecil \\
\hline سفيرج & Nama Buah (Hal. 679) & Buah kecil \\
\hline
\end{tabular}

Tetapi apabila huruf konsonan yang kelima adalah nun dari suffix (akhiran) انٌ, maka akhiran tersebut tetap dipakai. Contoh زعفران (za'farān) bentuk taṣgīrnya adalah زعيفران (zu'aifarān). Ada sejumlah pengecualian untuk bentukbentuk tașīr sebagaimana yang tersaji di bawah ini: 


\begin{tabular}{|c|c|c|c|}
\hline أبّ & Ayah & أبيّ & Ayah Kecil \\
\hline أخ & Saudara(lk) & 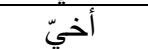 & Saudara kecil(lk) \\
\hline أخت & Saudara(pr) & أخية & Saudara kecil(pr) \\
\hline ابن & Anak(lk) & بنيّ & Anak kecil (lk) \\
\hline بنت/ابنة بنة & Anak (pr) & بنية & Anak kecil(pr) \\
\hline شيء & Sesuatu & شويّ/شويّة & Sesuatu kecil \\
\hline
\end{tabular}

Adapun fungsi sintaksis ism tasgīr dapat ditemukan dalam fungsi-fungsi berikut:

1. Pada nama diri. Contoh: حسن hasanun menjadi bentuk taṣgìr حسين husainun, bentuk عبد 'Abdullāh menjadi bentuk tașgìr 'ubaidullāh.

2. Pada arti khusus. Contoh: بحر bahrun (laut) menjadi bentuk taṣgir بحر كيـر buhairun (danau), كلب kalbun (anjing) menjadi bentuk taṣgīr كليب kulaibun (anjing kecil).

3. Pada tindakan yang mendatangkan kasih sayang. Contoh: ابن ibnun (anak laki-laki) menjadi benutk taṣgīr بنس bunayyun (anak kecil laki-laki) untuk menyebut dengan kasih sayang.

4. Pada ungkapan yang digunakan untuk merendahkan. Contoh: رجـ rajulun (orang laki-laki) menjadi bentuk taṣgir رجيل rujailun (orang kecil kaki-laki).

Pada umumnya, proses penamaan benda di dalam bahasa Arab tidak jauh beda dengan bahasa-bahasa lain di dunia ini. Dalam hal ini penulis lebih condong kepada pendapat Socrates (469-399 SM), guru Plato, yang mengemukakan bahwa nama harus sesuai dengan sifat acuan yang diberi nama. Pendapatnya merupakan kebalikan dari yang dikemukakan Aristotles. Namun lain halnya dengan penamaan benda-benda kecil di dalam bahasa Arab. Secara arbitrer dan konvensional penamaan benda-benda kecil dapat dibentuk berdasarkan pola ism tașgīr dari kata benda aslinya. Jadi penamaan bendabenda kecil di dalam bahasa Arab ada yang tidak perlu dengan menambahkan kata sifat disamping kata bendanya. Hal ini merupakan keunikan tersendiri dari penamaan benda di dalam bahasa Arab.

Pemberian nama benda-benda kecil sangat erat hubungannya dengan konsep ism tașgìr di dalam bahasa Arab.
Kata asli menderivasikan dirinya sendiri dengan wazan ism tasgī menjadi kata jadian yang memiliki makna benda berukuran kecil. Contoh: secara arbitrer dan konvensional orang Arab menyebut bolpen dengan قلم (qalamun). Kata tersebut berubah menjadi قليم (qulaimun) yang berarti bolpen kecil. Hal senada sebenarnya juga dapat diungkapkan dengan menyebut قلـم صــير (qalamun sagìrun), tapi pemanfaatan wazan ism taşgìr di dalam komunikasi bahasa Arab dianggap lebih memiliki kekayaan kosakata di dalam proses komunikasi.

Penamaan benda-benda kecil dalam bahasa Arab ini erat kaitannya dengan latar belakang penamaan dari segi penyebutan sebagian dan penyebutan sifat khas bukan pada peniruan bunyi, penyebutan penemu dan pembuat, tempat asal dan bahan.

\section{Kesimpulan}

Peranan konsep segitiga semantik sangat dominan dalam proses penamaan benda karena penamaan sangat melibatkan makna, simbol, dan acuan. Makna atau tanda adalah sesuatu yang dipindahkan kata atau sesuatu yang diungkap dari (hasil) hubungan antara penanda (kata) dengan petanda(benda atau seseorang atau sesuatu yang dipahami di luar bahasa). Simbol (ramzun) yaitu: tanda yang menjelaskan acuan/benda-nya melalui adanya makna istilah yang telah disepakati manusia, seperti: rambu-rambu lalu lintas, simbol, suara bel, dan sebagainya, termasuk juga kosakata bahasa, misalnya: شجرة (pohon), حصان (kuda), dan lain sebagainya. Acuan adalah sesuatu atau benda yang ditunjuk oleh kata/bahasa dan bertempat di luar kata/bahasa, baik sesuatu tersebut bersifat realistis, imajinatif, maupun ilusi. 
Secara morfologis proses penamaan benda-benda kecil di dalam bahasa Arab diperoleh dengan cara menambahkan morfem harakat dhammah, fatkhah, dan ya' sakinah pada sebuah kata benda. Apabila kata tersebut tersusun dari tiga huruf konsonan, maka wazan ism taṣgīr berupa فُعَيَل. Apabila kata tersebut tersusun dari empat huruf konsonan, maka wazannya adalah فُعَيلـنـ Adapun fungsi semantik ism taşgīr adalah sebagai nama diri, pernyataan arti khusus, tindakan yang mendatangkan kasih sayang, ungkapan untuk merendahkan seseorang.

\section{Daftar Pustaka}

Chaer, Abdul. 2003. Linguistik Umum. Jakarta: PT Rineka Cipta.

Cruse, D.A. 1986. Lexical Semantics. Cambridge: Cambridge University Press.

Ad-Dahdah, Anton. 1993. Mu'jamu Qawa'idil Lughatil-Arabiyyah (English Edition). Bairut: Maktabah Lubnan.

Djajasudarma, Fatimah. 1999. Semantik Satu Pengantar ke Arah Ilmu Makna. Bandung: Refika Aditama.

Al Ghulayaini, Asy Syaikh Musthofa. 2006. Jami'u Durus Al Arabiyyah. Beirut: Darul Fikri.

---------------. 1912. Ad Durus Al Arabiyyah Qismu Sharfi Minal Khalaqah Al Arabiyyah. Beirut: At Tab'ah Al Ahliyyah.

Haywood, J.A dan H.M Nahmad. 1969. A New Arabic Grammar of The Written Language. London: Percy Lund Humpries\&Co.1.td.
Ma'shum, Muhammad bin 'Ali, tanpa tahun. al-Amsilah al-Tasrifiyyah, Semarang: Pustaka al-'Alawiyyah

Mastoyo, Tri. 2007. Pengantar (Metode) Penelitian Bahasa. Yogyakarta: Penerbit Carasvatibooks.

Munawwir, Ahmad Warson. 2002. Al Munawir Kamus Arab Indonesia. Surabaya: Penerbit Pustaka Progressif.

Qobawah, Fakhruddin. 1998. Tasriful Asma' wal Af'al. Beirut: Maktabah Ma'arif.

Pateda, Mansoer. 2001. Semantik Leksikal. Jakarta: Penerbit Rineka Cipta.

Poerwadarminta, W.J.S. 1976. Kamus Umum Bahasa Indonesia. Jakarta: PN Balai Pustaka.

Ramlan, M. 2001. Morfologi Suatu Tinjauan Deskriptif. Yogyakarta: CV Karyono.

Sudaryanto, 1993. Aneka Metode dan Teknik Penelitian Bahasa. Yogyakarta: Pustaka Pelajar

Taufiqurrochman, H.R. 2008. Leksikologi Bahasa Arab. Malang. UIN Malang Press.

Verhaar, J. W. M. 2001. Asas-Asas Linguistik Umum. Yogyakarta: Gadjah Mada University Press.

*Penelitian ini dapat terselenggara atas Skim Penelitian Mandiri Aktif Universitas Sebelas Maret (UNS) Surakarta tahun 2020 dengan judul "Kesepadanan Gramatikal Arab Jawa Dalam Teks Keagamaan: Kajian Ekuivalensi Morfologi Dan Sintaksis”. 